Check for updates

Cite this: Phys. Chem. Chem. Phys., 2022, 24, 895

Received 2nd October 2021.

Accepted 4th November 2021

DOI: $10.1039 / \mathrm{d} 1 \mathrm{cp} 04518 \mathrm{k}$

rsc.li/pccp

\section{Impact of substitution on reactions and stability of one-electron oxidised phenyl sulfonates in aqueous solution $\dagger$}

\begin{abstract}
Tamas Nemeth, (D) *ab Tym de Wild, (D) ${ }^{a}$ Lorenz Gubler (D) ${ }^{a}$ and Thomas Nauser (D) *b
Highly reactive aromatic cation radicals have been invoked lately in synthetic routes and in the degradation pathways of hydrocarbon-based polymers. Changes in the electron density of aromatic compounds are expected to alter the reaction pathway following one electron oxidation through altering the $\mathrm{p} K_{\mathrm{a}}$ of the formed intermediate cation radical. Electron-donating groups increase its stability, however, little experimental data are known. While, in theory, the cation radical can be repaired by simple electron transfer, electron transfer to or from its deprotonated form, the hydroxycyclohexadienyl radical, will cause permanent modification or degradation. Time-resolved absorption spectroscopy indicates a $\mathrm{p} K_{\mathrm{a}} \approx 2-3$ for the 4-(tert-butyl)-2-methoxyphenylsulfonate (BMPS) radical cation, while its parent compound 4-(tert-butyl) phenylsulfonate (BPS) is much more acidic. The stability of both compounds towards oxidation by $\mathrm{HO}^{\bullet}$ was evaluated under air at $\mathrm{pH} 5$ and $\mathrm{pH} 0$. At $\mathrm{pH} 5$, both BMPS and BPS are unstable, and superstoichiometric degradation was observed. Degradation was slightly reduced for $\mathrm{BPS}$ at $\mathrm{pH}$ 0. In contrast, the more electron rich BMPS showed $80 \%$ lower degradation. We unambigously showed that in the presence of $\mathrm{Ce}(\mathrm{III})$ and $\mathrm{H}_{2} \mathrm{O}_{2}$ at $\mathrm{pH} \mathrm{O}$ both BMPS and BPS could be catalytically repaired via one electron reduction, resulting in further damage moderation.
\end{abstract}

\section{Introduction}

Aromatic cation radicals have been known for a long time. ${ }^{1,2}$ Important as they may be as intermediates in chemical reactions, their chemical properties have rarely been investigated. As electron-deficient aromatic systems they are Lewis acids ${ }^{3}$ and tend to have high electrode potentials, for unsubstituted benzene $E^{\circ}=2.7 \mathrm{~V}$ in acetonitrile has been reported. ${ }^{4}$ Merkel et al. showed that if the electron deficiency of the benzene cation radical was lowered by electron-donating groups, both Lewis-acidity and electrode potential decreased. ${ }^{4}$ They showcase the example of electron-donating methyl groups: with one methyl group, i.e. with toluene, the electrode potential is lowered by approximately $0.2 \mathrm{~V}$. With four methyl groups the potential is lowered by more than $0.6 \mathrm{~V} .{ }^{4}$ Despite such massive stabilisation of the cation radical, the potential in acetonitrile is still around $2 \mathrm{~V}$. Such high electrode potentials imply very high reactivities and, consequently, short lifetimes. Direct detection of such species therefore usually requires time-resolved methods.

\footnotetext{
${ }^{a}$ Electrochemistry Laboratory, Paul Scherrer Institut, 5232 Villigen PSI, Switzerland

${ }^{b}$ Laboratory of Inorganic Chemistry, ETH Zurich, Vladimir-Prelog-Weg 1, 8093 Zurich, Switzerland.E-mail: tamas.nemeth@psi.ch, nauser@inorg.chem.ethz.ch

$\dagger$ Electronic supplementary information (ESI) available. See DOI: 10.1039/d1cp04518k
}

Very reactive aromatic cation radicals are currently proposed for novel synthesis strategies involving $\mathrm{C}-\mathrm{H}$ amination of arenes, for example by the Ritter and by the Carreira groups. ${ }^{5,6}$ For optimal reaction yields, the reactivity of the intermediates is essential: if the stability of such cations is too high, they are of little use in synthesis. On the other hand, a too high instability will lead to unspecific reactions.

Aromatic cation radicals are also implied as crucial intermediates in stability discussion of proton-exchange membranes (PEMs) in fuel cells. ${ }^{7,8}$ During fuel cell operation hydroxyl radicals are produced. ${ }^{7,8}$ They will oxidise aromatic repetitive units that are often found in PEMs and may thereby limit their durability. As aromatic cation radicals are Lewis acids, they as such can undergo protolysis equilibria with water and form hydroxycyclohexadienyl radicals and protons (Scheme 1). ${ }^{8}$ Reduction of the cation radical may lead to repair whereas reduction of the cyclohexadienyl will lead to irreversible damage (Scheme 1). A protolysis equilibrium on the cyclohexadienyl side will increase the degradation rate of the PEM under normal operating conditions. ${ }^{7,8}$

Cation radicals of $p$-dimethoxybenzene-based materials are used in the charge-discharge cycle of organic redox-flow batteries. ${ }^{9}$ Also there, the stability of the cation radicals is of overmastering importance.

The IUPAC gold book cites Muller for the definition of a Lewis acid as "A molecular entity (and the corresponding 


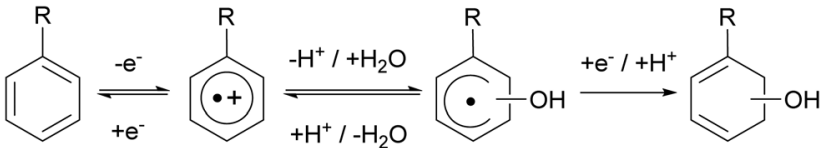

$\mathrm{R}=$ any group or $\mathrm{H}$

Scheme 1 Degradation and repair of aromatic compounds following one electron oxidation.

chemical species) that is an electron-pair acceptor and therefore able to react with a Lewis base to form a Lewis adduct, by sharing the electron pair furnished by the Lewis base". ${ }^{3}$ The definition is extended here to cover also radicals. As with all acid-base reactions, the reaction of a stronger acid with a given base results in a more exergonic reaction. Lower electron density of the cation radical means a higher Lewis acidity (and electrode potential) and, therefore, will manifest itself with a lower $\mathrm{p} K_{\mathrm{a}}$ in the reaction with water as the Lewis-base. In other words: for a given $\mathrm{pH}$, the position of the protolysis equilibrium of aromatic cation radicals depends on the ring's electron density. Compounds with higher electron density have a lower propensity to react with water and thus have a higher $\mathrm{p} K_{\mathrm{a}}\left(\mathrm{Ar}^{0^{+}}\right)$.

In this article, we experimentally assess whether these concepts do apply for simple compounds. We aim to directly observe the cation radical, find direct evidence for the $\mathrm{p} K_{\mathrm{a}}$ equilibrium and see if the predictions on the relative stabilities of cation radical vs. hydroxycyclohexadienyl radical are supported by product analysis.

Benzene is the simplest aromatic structure. However, its limited water-solubility makes it unsuitable for our experiments. Phenyl sulfonates retain the basic benzene structure with the advantage of having a solubility of tens of millimolar in water. We are not aware of any published experimental $\mathrm{p} K_{\mathrm{a}}$ values for either benzene or phenylsulfonate cation radicals. For methoxy-benzene (anisole) a $\mathrm{p} K_{\mathrm{a}}$ of about 2-3 has been reported. ${ }^{10}$ Phenyl cation radicals lack the electron-donating methoxy group of anisole and are, therefore, expected to be distinctly more acidic. The presence of a negatively charged sulfonate group may stabilize the cation radical and affect its $\mathrm{p} K_{\mathrm{a}}$.

Alkylated phenyl sulfonates are known building blocks of PEMs. ${ }^{8,11}$ However, their poor oxidative stability limits practical implementation: they react with $\mathrm{HO}^{\bullet}$, which is produced in the membrane and electrodes during the operation of the fuel cell. ${ }^{7}$ The reaction with aromatic groups is in essence diffusion controlled, ${ }^{8}$ with alkyl substituents it is at least an order of magnitude slower. ${ }^{12}$ Carbon-hydrogen bonds in alpha position to aromatic cation radicals are easily deprotonated. We therefore avoided such constituents, as their presence would introduce additional reaction pathways and thereby obscure the interpretation of results. Potassium 4-(tert-butyl) phenylsulfonate (BPS) and its more electron rich derivative, potassium 4-(tert-butyl)-2-methoxyphenylsulfonate (BMPS), were chosen as model structures in this study (Fig. 1). Tert-Butyl groups are

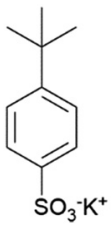

BPS

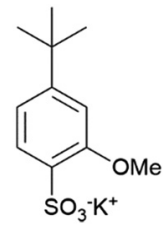

BMPS
Fig. 1 Structure of the aromatic phenyl sulfonates, selected as model compounds in this study.

electron donating and will lower the acidity of cation radicals. ${ }^{3}$ The reduction of cation radicals produced by oxidation with $\mathrm{HO}^{\bullet}$ is pivotal for strategies to improve durability of PEMs. ${ }^{7,8}$ Our results may be applicable in that field.

We produced radicals by water radiolysis, reaction (1), where $90 \%$ of the primary radicals are $\mathrm{HO}^{\bullet}$ and $\mathrm{e}_{\mathrm{aq}}{ }^{-12-14}$ With suitable additives, the electrons can be converted into oxidising radicals, reactions (2) and (3). ${ }^{12}$

$$
\begin{gathered}
\mathrm{H}_{2} \mathrm{OHO}^{\bullet}+\mathrm{H}^{\bullet}+\mathrm{e}_{\mathrm{aq}}^{-}+\mathrm{H}^{+}+\mathrm{H}_{2}+\mathrm{H}_{2} \mathrm{O}_{2} \\
\mathrm{~N}_{2} \mathrm{O}+\mathrm{H}_{2} \mathrm{O}+\mathrm{e}_{\mathrm{aq}}{ }^{-} \rightarrow \mathrm{N}_{2}+\mathrm{HO}^{\bullet}+\mathrm{HO}^{-} \\
\mathrm{S}_{2} \mathrm{O}_{8}{ }^{2-}+\mathrm{e}_{\mathrm{aq}}{ }^{-} \rightarrow \mathrm{SO}_{4}{ }^{\bullet-}+\mathrm{SO}_{4}{ }^{2-}
\end{gathered}
$$

This methodology can be applied to produce a continuous source of a low concentration of radicals in gamma-radiolysis. Alternatively, pulses of ionizing radiation with high intensity can be used for time-resolved experiments in pulse-radiolysis.

\section{Experimental}

\section{Chemicals and apparatus}

Free acids of potassium 4-(tert-butyl) phenylsulfonate (BPS) and potassium 4-(tert-butyl)-2-methoxyphenylsulfonate (BMPS) were synthesized according to literature procedures, ${ }^{15,16}$ then were neutralized with $\mathrm{KOH}$ solution to yield the potassium salts (analytics below). Sulfuric acid 95\% (Fischer Scientific), cerium(III) sulfate anhydrous $99.99 \%$ (Sigma Aldrich), manganese sulfate monohydrate $99.9 \%$ (Sigla Aldrich), sodium sulfate decahydrate 99.0\% (Sigma Aldrich) and potassium peroxodisulfate, 2,2'-azino-bis(3ethylbenzothiazoline-6-sulfonic acid) diammonium salt (ABTS) were used as received. Ultra-pure water was provided by a Milli-Q or Evoqua Ultra Clear UV Plus water purification system. Organic solvents were of HPLC grade.

\section{Methods and apparatus}

Purity of the compounds was evaluated using an Acquity UPLC $\mathrm{H}$-class system (Waters, Milford, USA), gradient elution of AcN: $\mathrm{H}_{2} \mathrm{O}$ solvent system containing $0.025 \% \mathrm{HCOOH}$ acidic additive (1 $\mu \mathrm{L}$ injection, Waters Acquity C18 column $1.7 \mu \mathrm{m}$, $2.1 \times 50 \mathrm{~mm}$, Part No. 186002350) and was found to be $>99 \%$. For the quantification of the degree of BPS and BMPS degradation, the same instrument and method were used.

Pulse radiolysis experiments were carried out with the $2 \mathrm{MeV}$ Febetron 705 accelerator of ETH, which has a pulse-width of 
approximately $50 \mathrm{~ns} .{ }^{17,18}$ Absorbed doses were determined by KSCN dosimetry, based on $G=0.635 \mu \mathrm{mol} \mathrm{J}{ }^{-1}$ and $\varepsilon_{472}=7580 \mathrm{M}^{-1} \mathrm{~cm}^{-1}$. The dose is measured in Gray, where $1 \mathrm{~Gy}=1 \mathrm{~J} \mathrm{~kg}^{-1}$ or in water $\approx 1 \mathrm{~J} \mathrm{~L}^{-1}$. Typically, a $10 \%$ uncertainty is associated with the dose. The identity of the oxidizing cation radicals were evaluated using ABTS $\left(E^{\circ}\left(\mathrm{ABTS}^{\bullet-} / \mathrm{ABTS}^{2-}\right)=0.68 \mathrm{~V}\right) .{ }^{19,20}$ The formation of ABTS was monitored at one of its absorbance maxima, $650 \mathrm{~nm}$, where only $\mathrm{ABTS}^{\bullet-}$ absorbs with $\varepsilon_{650}=13000 \mathrm{M}^{-1} \mathrm{~cm}^{-1} \cdot{ }^{21}$ Pulse radiolysis experiments were carried out at constant ionic strength of $I \approx 0.33 \mathrm{M}$, with exception of an experiment at $\mathrm{pH}=1$ where $I \approx 0.42 \mathrm{M}$. For continuous radiolysis, samples were exposed to $138 \mathrm{~Gy} / \mathrm{h}{ }^{60} \mathrm{Co} \gamma$-radiation at the irradiation facility of PSI (Gammacell 220, Atomic Energy of Canada Limited). Steady-state $\gamma$-radiolysis experiments were carried out at an ionic strength of approximately $1 \mathrm{M}$. All samples were air saturated because the setup currently does not allow for experiments with deaerated samples.

\section{Results and discussion}

\section{Pulse radiolysis experiments}

Aqueous solutions of BMPS and BPS were one-electron oxidised by $\mathrm{HO}^{\bullet}$ or $\mathrm{SO}_{4}{ }^{\bullet-}$ radicals and the reactions were followed by time-resolved UV-Vis spectrometry. These highly oxidising radicals were produced via pulse radiolysis. Briefly, free radical chemistry is initiated when a dilute aqueous solution containing the compound of interest is exposed to nanosecond pulses of ionising irradiation. Water radiolysis by ionising radiation produces primary species, $\mathrm{HO}^{\bullet}(45 \%), \mathrm{H}^{\bullet}(10 \%)$ and $\mathrm{e}_{\mathrm{aq}}-$ (45\%), with known yields: $G\left(\mathrm{HO}^{\bullet}\right)=G\left(\mathrm{e}_{\mathrm{aq}}{ }^{-}\right)=0.28 \mu \mathrm{mol} \mathrm{J}{ }^{-1}$ and $G\left(\mathrm{H}^{\bullet}\right)=0.06 \mu \mathrm{mol} \mathrm{\textrm {J } ^ { - 1 }}$, reaction (1), at neutral $\mathrm{pH}^{.{ }^{2-14}}$ These yields are also correct for dilute aqueous solutions. In $\mathrm{N}_{2} \mathrm{O}$-saturated aqueous solutions $\left(24.8 \mathrm{mM}\right.$ at $\left.20{ }^{\circ} \mathrm{C}\right) \mathrm{e}_{\mathrm{aq}}{ }^{-}$can be converted to $\mathrm{HO}^{\bullet}$ via reaction (2), thus increasing the yield to

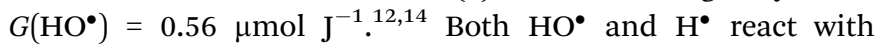
aromatic compounds (Ar) with near diffusion-limited rates. This leads to the formation of hydroxycyclohexadienyl and cyclohexadienyl radicals, ${ }^{2,23}$ HO-adducts and H-adducts, respectively (reactions (4) and (5)). In low pH solutions cation radicals are formed indirectly through acid-catalysed water elimination according to reaction (6). ${ }^{8,10}$ Alternatively, cation radicals are also formed directly via the reaction of $\mathrm{SO}_{4}{ }^{\bullet-}$, produced in pulse irradiated $\mathrm{S}_{2} \mathrm{O}_{8}{ }^{2-}$ solution by its reaction with $\mathrm{e}_{\mathrm{aq}}{ }^{-}$, reaction (7). ${ }^{12}$ The reaction with $\mathrm{HO}^{\bullet}$, reaction (4), can be supressed by scavenging it with $t$ - $\mathrm{BuOH}$, according to reaction (8). ${ }^{12}$

$$
\begin{gathered}
\mathrm{Ar}+\mathrm{HO}^{\bullet} \rightarrow(\mathrm{Ar} \cdots \mathrm{OH})^{\bullet} \\
\mathrm{Ar}+\mathrm{H}^{\bullet} \rightarrow(\mathrm{Ar} \cdots \mathrm{H})^{\bullet} \\
(\mathrm{Ar} \cdots \mathrm{OH})^{\bullet}+\mathrm{H}^{+} \leftrightarrows \mathrm{Ar}^{\bullet+}+\mathrm{H}_{2} \mathrm{O} \\
\mathrm{Ar}+\mathrm{SO}_{4}^{\bullet-} \rightarrow \mathrm{Ar}^{\bullet+}+\mathrm{SO}_{4}{ }^{2-} \\
\mathrm{HO}^{\bullet}+\mathrm{C}\left(\mathrm{CH}_{3}\right)_{3} \mathrm{OH} \rightarrow \mathrm{H}_{2} \mathrm{O}+{ }^{\bullet} \mathrm{CH}_{2} \mathrm{C}\left(\mathrm{CH}_{3}\right)_{2} \mathrm{OH}
\end{gathered}
$$

If an argon-saturated solution of $10 \mathrm{mM}$ BMPS, $100 \mathrm{mM} \mathrm{K}_{2} \mathrm{~S}_{2} \mathrm{O}_{8}$ and $10 \mathrm{mM} \mathrm{H}_{2} \mathrm{SO}_{4}$ is pulse irradiated, we observe the build-up
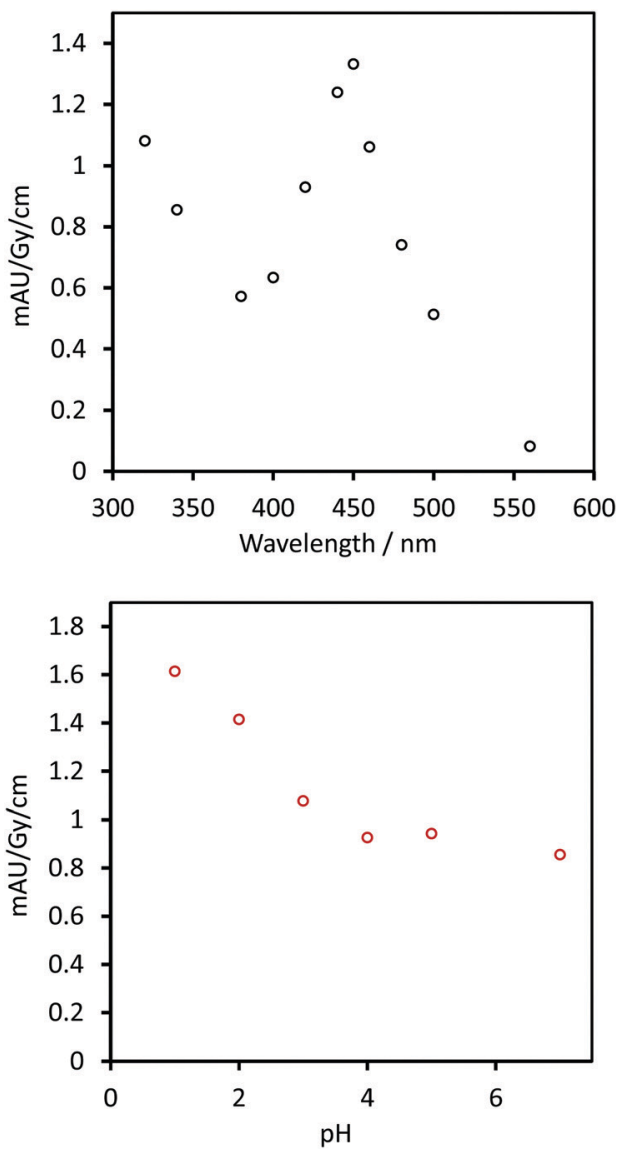

Fig. 2 Top: Transient absorption spectra $5 \mu$ s after the pulse (dose 12-32 Gy), obtained from time-resolved absorbance readings, normalized to $1 \mathrm{~Gy}$, measured in argon-saturated solutions that contained $10 \mathrm{mM} \mathrm{BMPS}, 0.1 \mathrm{M} \mathrm{K}_{2} \mathrm{~S}_{2} \mathrm{O}_{8}$ and $10 \mathrm{mM} \mathrm{H}_{2} \mathrm{SO}_{4} \cdot \varepsilon_{450 \mathrm{~nm}} \approx 3 \times 10^{3} \mathrm{M}^{-1} \mathrm{~cm}^{-1}$, see details in ESI. $\dagger$ Bottom: $\mathrm{pH}$ dependence of absorbance at $\lambda=450 \mathrm{~nm}, 5 \mu \mathrm{s}$ after the pulse, measured in argon-saturated solutions that contained $10 \mathrm{mM}$ BMPS, $0.1 \mathrm{M} \mathrm{K}_{2} \mathrm{~S}_{2} \mathrm{O}_{8}$ at $\mathrm{pH}=1-7$. The absorbances were corrected for the competitive reaction $\mathrm{e}_{\mathrm{aq}}{ }^{-}+$ $\mathrm{H}^{+} \rightarrow \mathrm{H}^{\bullet}$, see the ESI, $\dagger$ for details of yields correction.

of an absorption with a maximum at $450 \mathrm{~nm}$ (Fig. 2 top). Under these conditions mainly $\mathrm{HO}^{\bullet}\left(\mathrm{G}_{\left(\mathrm{HO}^{\bullet}\right)}=0.28\right)$ and $\left.\mathrm{SO}_{4}{ }^{\bullet-}\left(\mathrm{G}_{\left(\mathrm{SO}_{4}\right.}{ }^{-}\right)=0.224\right)$ are formed and dominate the system initiating electron transfer with BMPS. In the absence of BMPS no such product is formed. Addition of $900 \mathrm{mM} t$-BuOH to the solution above decreased this absorbance by $\sim 60 \%$, confirming the successful scavenging of $\mathrm{HO}^{\bullet}$ (reaction (8), Fig. S1, ESI $\dagger$ ). Fig. 2 bottom shows the $\mathrm{pH}$ dependence of the absorbance at $450 \mathrm{~nm}$. Under the assumption that the larger absorption at low $\mathrm{pH}$ can be attributed mainly to $\mathrm{BMPS}^{\bullet+}$, the data align well with the notion of a $K_{\mathrm{a}}$ of $2-3$, as for anisole. ${ }^{10}$

\section{The cation radical can be observed at $450 \mathrm{~nm}$}

We then pulse-irradiated the argon-saturated solution of $10 \mathrm{mM}$ BMPS, $100 \mathrm{mM} \mathrm{K} \mathrm{S}_{2} \mathrm{O}_{8}$ and $10 \mathrm{mM} \mathrm{H}_{2} \mathrm{SO}_{4}$ in the presence of $1.5 \mathrm{mM} \mathrm{Ce}(\mathrm{III})$, which is a weak reductant $\left(E^{\circ}=\right.$ $+1.44 \mathrm{~V}),{ }^{24}$ Fig. 3. The absorbance decrease at $450 \mathrm{~nm}$ was clearly accelerated, reaction (9), which indicates that the 


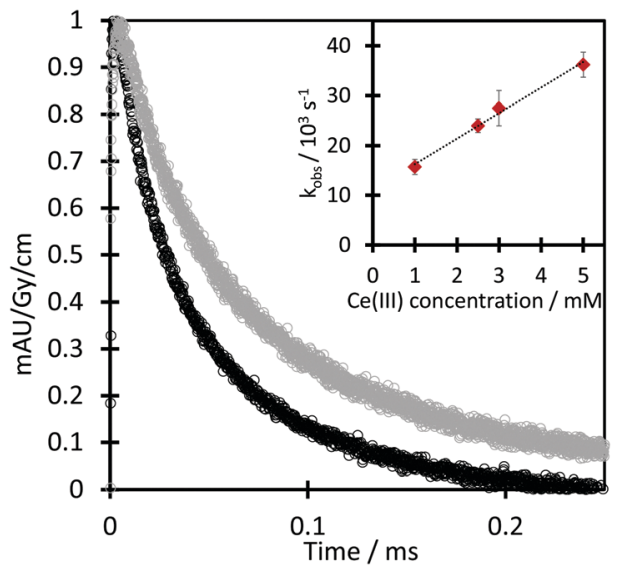

Fig. 3 Pseudo-first-order decay of $\mathrm{BMPS}^{\bullet+}$ in the absence (grey) and presence (black) of $1.5 \mathrm{mM} \mathrm{Ce}(\mathrm{III})$ in argon-saturated solutions that contained $10 \mathrm{mM}$ BMPS, $100 \mathrm{mM} \mathrm{K}_{2} \mathrm{~S}_{2} \mathrm{O}_{8}, 10 \mathrm{mM} \mathrm{H}_{2} \mathrm{SO}_{4}$ and 0 or $0.75 \mathrm{mM}$ $\mathrm{Ce}_{2}\left(\mathrm{SO}_{4}\right)_{3}$ (recorded at $25^{\circ} \mathrm{C}$ ). Dose: $16-32 \mathrm{~Gy}$, note that there is a $\sim 10 \%$ error associated with the dose. Inset: Pseudo-first-order rate constants for the reaction of the species formed at $450 \mathrm{~nm}$ of $10 \mathrm{mM}$ BMPS (red diamonds) with $0-5 \mathrm{mM} \mathrm{Ce}(\mathrm{II})$ as a function of concentration. Data were taken at room temperature in irradiated (dose of ca. 9-28 Gy) argon saturated $100 \mathrm{mM} \mathrm{K} \mathrm{S}_{2} \mathrm{O}_{8}$ solutions that contained $10 \mathrm{mM} \mathrm{H}_{2} \mathrm{SO}_{4}$ and $900 \mathrm{mM} t-\mathrm{BuOH}$.

observed species is indeed a strong oxidant, in agreement with the tentative assignment of this band to BMPS ${ }^{\bullet+}$.

$$
\mathrm{BMPS}^{\bullet+}+\mathrm{Ce}(\mathrm{III}) \rightarrow \text { BMPS }+ \text { Ce(Iv) }
$$

The rate constant for reaction (9), $k_{9}$, was obtained by pulse radiolysis of an argon-saturated solution of $10 \mathrm{mM}$ BMPS, 0-5 mM Ce(III), $100 \mathrm{mM} \mathrm{K}_{2} \mathrm{~S}_{2} \mathrm{O}_{8}, 10 \mathrm{mM} \mathrm{H}_{2} \mathrm{SO}_{4}$ and $900 \mathrm{mM}$ $t$-BuOH. A rate constant of $k_{9}=(5.1 \pm 0.3) \times 10^{6} \mathrm{M}^{-1} \mathrm{~s}^{-1}$ was derived from the slope of the plot $k_{\mathrm{obs}} v s$. [Ce(III)], where $k_{\mathrm{obs}}$ is the pseudo first-order rate constant associated with the observed absorption decay at $450 \mathrm{~nm}$ (Fig. 3 inset).

As an additional control, ABTS was used as a redox indicator. While its electrode potential is only $E^{\circ}\left(\mathrm{ABTS}^{\bullet-} / \mathrm{ABTS}^{2-}\right)=$ $0.68 \mathrm{~V}^{20}$ as compared to $E^{\circ}\left(\mathrm{BMPS}^{\bullet+} / \mathrm{BMPS}\right)>1.44 \mathrm{~V}$ (oxidation of $\mathrm{Ce}(\mathrm{III})$, see above) and to aliphatic carbon centred radicals $E^{\circ}\left(\mathrm{R}_{3} \mathrm{C}^{\bullet}, \mathrm{H}^{+} / \mathrm{R}_{3} \mathrm{C}-\mathrm{H}\right) \gtrsim 1 \mathrm{~V}$ at $\mathrm{pH} 7 . \neq$ From a thermodynamic point of view, therefore, one might expect both cation radicals and cyclohexadienyl radicals to oxidise ABTS. However, Wolfenden and Willson showed that aliphatic carbon-centred radicals do not react with ABTS. ${ }^{19}$ Formation of the ABTSradicals is, therefore, a suggestive hint to the presence of cation radicals, reaction (10). Pulse radiolysis of $\mathrm{N}_{2} \mathrm{O}$-saturated solutions of $10 \mathrm{mM}$ BMPS, $0.5 \mathrm{mM}$ ABTS, $300 \mathrm{mM} \mathrm{NaClO} 4$ and $10 \mathrm{mM} \mathrm{H}_{2} \mathrm{SO}_{4}$ resulted in a fast absorbance build-up at $650 \mathrm{~nm}$, a wavelength where only $\mathrm{ABTS}^{\bullet-}$ absorbs (Fig. 4).

$$
\mathrm{BMPS}^{\bullet+}+\mathrm{ABTS} \rightarrow \mathrm{BMPS}+\mathrm{ABTS}^{\bullet+}
$$

\# Equilibrium constants for $\mathrm{RS}^{\bullet}+\mathrm{R}_{3} \mathrm{CH} \rightarrow \mathrm{RSH}+\mathrm{R}_{3} \mathrm{C}^{\bullet}$ are around 0.1 for stabilized carbon centred radicals. ${ }^{30}$ As $E^{\circ \prime}\left(\mathrm{RS}^{\bullet}, \mathrm{H}^{+} / \mathrm{RS}-\mathrm{H}\right) \approx 1 \mathrm{~V}$ at $\mathrm{pH} 7$, the value for carbon centred radicals is expected to be slightly higher.

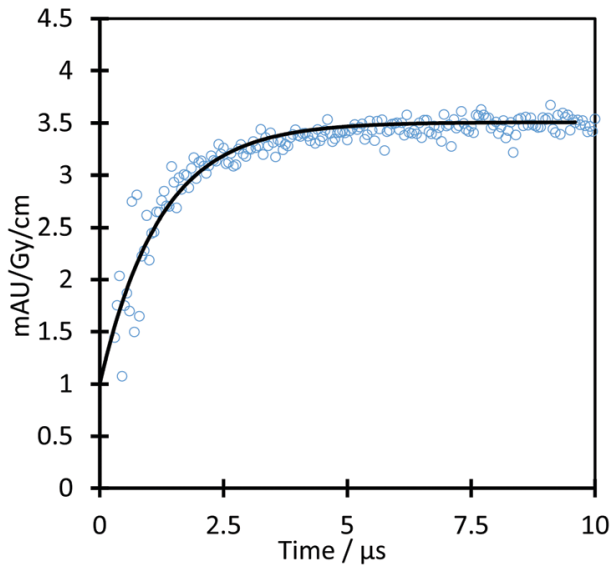

Fig. 4 Redox titration performed in $\mathrm{N}_{2} \mathrm{O}$-saturated solution containing $10 \mathrm{mM}$ BMPS, $0.5 \mathrm{mM}$ ABTS, $300 \mathrm{mM} \mathrm{NaClO}_{4}$ and $10 \mathrm{mM} \mathrm{H}_{2} \mathrm{SO}_{4}$. Evaluated at $650 \mathrm{~nm}$ (blue circles) by performing a first order fit on the dataset (black line), $k_{\mathrm{obs}}=8 \times 10^{5} \mathrm{~s}^{-1}$.

From a first order fit to the dataset a pseudo-first order rate constant of $k_{\text {obs }}=8 \times 10^{5} \mathrm{~s}^{-1}$ was obtained, therefore $k_{10} \approx$ $1.6 \times 10^{9} \mathrm{M}^{-1} \mathrm{~s}^{-1}$. In line with the assumption that predominantly cation radicals react with ABTS we found the yield at this wavelength to decrease with increasing $\mathrm{pH}$ (data not shown). At low $\mathrm{pH}$ the reaction was nearly quantitative (see ESI, $\uparrow$ for details).

\section{Stability assessment by product analysis}

We initially claimed that degradation of one-electron oxidised aromatic groups was $\mathrm{pH}$-dependent and can be affected by electron-donating or withdrawing groups. Therefore, we compared the oxidative stability of BMPS and its non-methoxylated parent compound, BPS, at different $\mathrm{pH}$ values. Air saturated solutions of $1 \mathrm{mM}$ BMPS at $\mathrm{pH}=0\left(1 \mathrm{M} \mathrm{H}_{2} \mathrm{SO}_{4}\right)$ or $\mathrm{pH}=5(5 \mu \mathrm{M}$ $\mathrm{H}_{2} \mathrm{SO}_{4}$ ), containing either no $\mathrm{Ce}(\mathrm{III})$ and no $\mathrm{H}_{2} \mathrm{O}_{2}$ or, alterna-

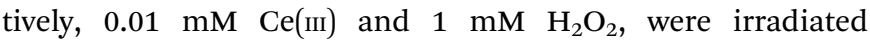
with $\gamma$-radiation from a ${ }^{60} \mathrm{Co}$ source to form ${ }^{\bullet} \mathrm{OH}$ radicals by the radiolysis of water. In contrast to the pulse radiolysis experiments, the solutions were air-saturated and contained approximately $200 \mu \mathrm{M} \mathrm{O}$. The degree of degradation was quantified by UPLC-UV.

Observation of a chain reaction. As can been seen in Fig. 5 bottom, for BMPS the degradation was strongly accelerated at higher $\mathrm{pH}$. If all $\mathrm{HO}^{\bullet}$ radicals were to react with BMPS, in case of a stoichiometric yield, all measurement points would fall onto the grey line. Measurements below that line, i.e. substoichiometric turnover, indicate presence of competition reactions. Measurements above that line require presence of a chain reaction. This is observed at $\mathrm{pH}=5$, where more than one equivalent of BMPS was consumed per oxidising radical. Because of the efficient reactant consumption, the relative degradation yield decreased significantly at increased oxidant levels (Fig. 5 bottom). It appears that oxygen strongly promotes degradation under these conditions. The reducing cyclohexadienyl radicals are likely to react with oxygen, reaction (11). ${ }^{25}$ 

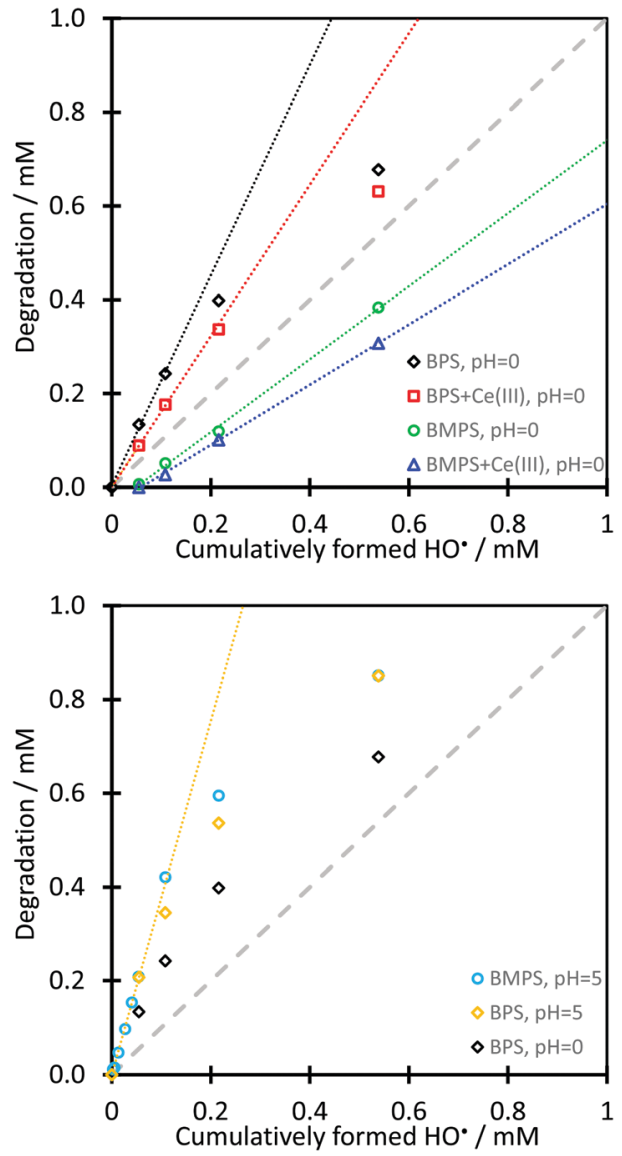

Fig. 5 Top: Degree of degradation of air-saturated solutions of $1 \mathrm{mM}$ BMPS or $1 \mathrm{mM}$ BPS as a function of the total amount of formed $\mathrm{HO}^{\bullet}$ at $\mathrm{pH}=0$ in the absence (green circles and black diamonds) or presence of $0.01 \mathrm{mM} \mathrm{Ce}(\mathrm{II})$ and $1 \mathrm{mM} \mathrm{H}_{2} \mathrm{O}_{2}$ (blue triangles and red squares). Bottom: At $\mathrm{pH}=5$ in the absence of $\mathrm{Ce}(\mathrm{III})$ and $\mathrm{H}_{2} \mathrm{O}_{2}$ (blue circles and orange diamonds), the data for BPS at $\mathrm{pH}=0$ is shown as reference (black diamonds). At $\mathrm{pH}=5$ ionic strength was adjusted with $0.333 \mathrm{M} \mathrm{Na}_{2} \mathrm{SO}_{4}$.

$$
\operatorname{Ar}(-\mathrm{OH})^{\bullet}+\mathrm{O}_{2} \rightarrow \operatorname{Ar}(-\mathrm{OH})\left(-\mathrm{O}_{2}\right)^{\bullet} \rightarrow \text { products }
$$

The peroxyl radical intermediate in reaction (11) is a reactive oxidative species and possibly responsible for the superstoichiometric turnover found (Fig. 5 bottom). As stated above, cation radicals can be repaired by simple one electron reduction, whereas the hydroxycyclohexadienyl radicals cannot (Scheme 1). One-electron oxidation leads to the hydroxylated product, one-electron reduction to a reactive cyclohexadiene (Scheme 1).

pH - dependence of degradation. At $\mathrm{pH}=5$ the degradation yields of $1 \mathrm{mM}$ BPS were similar to those of BMPS (Fig. 5 bottom). Both compounds were more stable at $\mathrm{pH}=0$ (Fig. 5 top, black diamonds (BPS) and green circles (BMPS)). However, the ratios (degradation at $\mathrm{pH}=5) /($ degradation at $\mathrm{pH}=0$ ) are very different. For BPS, we observed a value of approx. 1.6, for BMPS the value was around 5. Equilibrium (6) may be the key for a detailed explanation of our data. If indeed $\mathrm{p} K_{6}\left(\mathrm{BMPS}^{\bullet+}\right) \approx$ 2 , then at $\mathrm{pH}=0$ around $99 \%$ of the one-electron oxidised species are present as cation radicals, BMPS $^{\bullet+}$, and $1 \%$ as cyclohexadienyl radicals, (BMPS $\cdots \mathrm{OH})^{\bullet}$. With the electron donating methoxy group lacking, $\mathrm{p} K_{6}\left(\mathrm{BPS}^{\bullet+}\right)$ is expected to be clearly lower than $\mathrm{p}_{6}\left(\mathrm{BMPS}^{\bullet+}\right) \approx 2$. In other words, there is a significant percentage of radicals in the more vulnerable hydroxycyclohexadienyl form even at $\mathrm{pH}=0$. In consequence we observe that at $\mathrm{pH}=0 \mathrm{BPS}$ is significantly less protected from degradation than BMPS and there is an increased degradation at $\mathrm{pH}=5$ for both BPS and BMPS.

When $10 \mu \mathrm{M} \mathrm{Ce}(\mathrm{III})$ and $1 \mu \mathrm{mM} \mathrm{H}_{2} \mathrm{O}_{2}$ were added to the solutions of $1 \mathrm{mM}$ BMPS or $1 \mathrm{mM}$ BPS at $\mathrm{pH}=0$, the degradation was suppressed even more (Fig. 5 top, red squares (BPS) and blue triangles (BMPS)). This supports the notion of the formation of a strongly oxidising BMPS $^{\bullet+}$ or $\mathrm{BPS}^{\bullet+}$ that can be repaired by a mediocre reductant like Ce(III) (Fig. 4 and reaction (9)).

With the highest irradiation doses, we observed more repaired BMPS ( $80 \mu \mathrm{M}$ less degradation than the control) than there was added Ce(III) $(10 \mu \mathrm{M})$. We explain this in terms of reaction (12), where $\mathrm{Ce}(\mathrm{IV})$ is reduced back to $\mathrm{Ce}(\mathrm{III})$ by $\mathrm{H}_{2} \mathrm{O}_{2}$.

$$
\mathrm{Ce}(\mathrm{Iv})+\mathrm{H}_{2} \mathrm{O}_{2} \rightarrow \mathrm{Ce}(\mathrm{III})+\mathrm{HOO}^{\bullet}+\mathrm{H}^{+}
$$

We cannot provide experimental data for $\mathrm{p} K_{6}\left(\mathrm{BPS}^{\bullet+}\right)$. There is, however, an indication of a value of $\leq 0$. Decrease of the $\mathrm{pH}$ from 5 to 0 only moderately protects BPS from degradation (Fig. 5). Under the assumption that degradation proceeds mainly via hydroxycyclohexadienyl radicals, turnover rates should be proportional to their respective concentration. Then at $\mathrm{pH}=\mathrm{p} K_{\mathrm{a}}$ the ratio (degradation at $\left.\mathrm{pH}=5\right) /($ degradation at $\mathrm{pH}=0$ ) should be 2 . The observed value of 1.6 is smaller than that, indicating $\mathrm{p}_{6}\left(\mathrm{BPS}^{\bullet+}\right)<0$.

At $\mathrm{pH}=5$, with BPS and with BMPS, we observed no decrease in the degree of degradation upon addition of both Ce(III) and $\mathrm{H}_{2} \mathrm{O}_{2}$ (Fig. S2, ESI $\dagger$ ). This is only possible if reaction (9) becomes negligible and, therefore the concentration of BMPS ${ }^{\bullet+}$ and $\mathrm{BPS}^{\bullet+}$ must be low. This further supports that the $\mathrm{p} K_{\mathrm{a}}$ of both cation radicals is below 3 .

Control experiments at $\mathrm{pH}=0$ showed increased degradation if only Ce(III) was added. Likewise, increased degradation was also observed if only $\mathrm{H}_{2} \mathrm{O}_{2}$ was added. Therefore, we assume to observe catalytic repair via reactions (9) and (12). In preparative chemistry, nucleophilic radical attack is a known mechanism. ${ }^{26}$ To produce near quantitative yield, an oxidative transition metal is added to the reaction in order to oxidise the formed intermediate cyclohexadienyl radicals because the latter are good reductants. Rate constants of up to $3 \times 10^{9} \mathrm{M}^{-1} \mathrm{~s}^{-1}$ are reported, which is practically diffusion controlled. ${ }^{27}$ An analogous mechanism may be operative in our experiments in the presence of $\mathrm{Ce}(\mathrm{III})$ and absence of $\mathrm{H}_{2} \mathrm{O}_{2}$ at $\mathrm{pH}=0 . \mathrm{Ce}(\mathrm{Iv})$ produced via reaction (9) may facilitate the production of unstable phenols.

$\S E^{\circ}\left(\mathrm{HO}^{\circ}, \mathrm{H}^{+} / \mathrm{H}_{2} \mathrm{O}\right)=2.7 \mathrm{~V}, E^{\circ}\left(\mathrm{HOO}^{\bullet}, \mathrm{H}^{+} / \mathrm{H}_{2} \mathrm{O}_{2}\right)=1.5 \mathrm{~V},{ }^{31}$ the electrode potential $E^{\circ}\left(\mathrm{Ce}(\mathrm{Iv}) / \mathrm{H}^{+}, \mathrm{Ce}(\mathrm{III})\right)$ in water is strongly dependent on the electrolyte, $1.3-1.7 \mathrm{~V}{ }^{32}$ Given that reactions (9) and (12) are one-sided, hydroperoxyl radicals will not oxidise the aromatic structures used here. 


\section{Conclusion}

We successfully demonstrated that an electron-donating group indeed increased the $\mathrm{p} K_{\mathrm{a}}$ of an aromatic cation radical. Correspondingly, degradation was slowed down if the equilibrium was more on the side of the cation radical. Application of a suitable reductant to the cation radical further lowered the yield of degradation.

Reaction of $\mathrm{SO}_{4}{ }^{--}$and $\mathrm{HO}^{\bullet}$ with BMPS leads to the formation of a species with an absorption maximum at $450 \mathrm{~nm}$ (Fig. 2). The absorption is pH-dependent (Fig. 2. inset) and can be quenched by the one-electron reductants ABTS and Ce(III) (Fig. 3 and 4). ${ }^{19,24}$ We therefore assigned it to the cation radical BMPS $^{\bullet+}$, which is in a protolysis equilibrium with hydroxycyclohexadienyl radical (equilibrium (6)). The ${ }^{60} \mathrm{Co}$ experiments indicated that the degree of degradation under oxidizing conditions is conditional, at a given $\mathrm{pH}$, to the $\mathrm{p} K_{\mathrm{a}}$ of the aromatic compound, BMPS or BPS in this study (Fig. 5).

In the treatments of wastewater rich in aromatic compounds, a high degradation yield is required. ${ }^{28}$ Our results show that by establishing a $\mathrm{pH}$ well above the $\mathrm{p} K_{\mathrm{a}}$ of the associated protonation equilibria this objective can be achieved, in analogy to the results presented in Fig. 5 .

In the presence of the weak reductant $\mathrm{Ce}(\mathrm{III})$ the degree of degradation could be favorably altered (Fig. 5). We unambiguously proved that repair of the oxidized cation radical of both BPS and BMPS is possible, according to reaction (9). BPS is the monomer analogous compound of $\alpha$-methylstyrene sulfonatebased proton exchange fuel cell membranes. ${ }^{8,29}$ Our findings have implications for the judicious development of fuel cell membranes: for the first time, catalytic repair of aromatic cation radicals by the combination of a transition metal and hydrogen peroxide has been experimentally demonstrated.

The presence of acid-stable electron-donating groups in combination with catalytic repair is a viable synthetic strategy to improve membrane durability.

\section{Author contributions}

T. Nemeth synthesised, purified and characterized BPS and BMPS, was responsible for the curation and analysis of data, and developed the methodology used in the degradation studies. T. de Wild took part in the data curation. L. Gubler was essential for the conceptualization of the project, securing funds and for project supervision. T. Nauser conceptualized this study and, together with T. Nemeth, was responsible for the design of the experiments, interpretation of the data and the writing of the manuscript.

\section{Conflicts of interest}

There are no conflicts to declare.

\section{Acknowledgements}

The authors wish to thank the Swiss National Science Foundation (SNSF) for project funding (grant no. 175493). Dr Thomas
Nauser greatly appreciates the continuing support of Prof. Detlef Günther (ETH Zurich).

\section{Notes and references}

1 A. C. Albrecht and W. T. Simpson, J. Am. Chem. Soc., 1955, 77(17), 4454-4461.

2 N. Zhang, S. R. Samanta, B. M. Rosen and V. Percec, Chem. Rev., 2014, 114(11), 5848-5958.

3 P. Muller, Pure Appl. Chem., 1994, 66, 1077-1184.

4 P. B. Merkel, P. Luo, J. P. Dinnocenzo and S. Farid, J. Org. Chem., 2009, 74, 5163-5173.

5 W. S. Ham, J. Hillenbrand, J. Jacq, C. Genicot and T. Ritter, Angew. Chem., Int. Ed., 2019, 58, 532-536.

6 S. L. Rossler, B. J. Jelier, P. F. Tripet, A. Shemet, G. Jeschke, A. Togni and E. M. Carreira, Angew. Chem., Int. Ed., 2019, 58, 526-531.

7 L. Gubler, T. Nauser, F. D. Coms, Y.-H. Lai and C. S. Gittleman, J. Electrochem. Soc., 2018, 165, F3100-F3103.

8 T. de Wild, T. Nemeth, T. M. Nolte, T. J. Schmidt, T. Nauser and L. Gubler, J. Electrochem. Soc., 2021, 168, 054514.

9 J. Huang, B. Pan, W. Duan, X. Wei, R. S. Assary, L. Su, F. R. Brushett, L. Cheng, C. Liao, M. S. Ferrandon, W. Wang, Z. Zhang, A. K. Burrell, L. A. Curtiss, I. A. Shkrob, J. S. Moore and L. Zhang, Sci. Rep., 2016, 6, 32102.

10 P. O'Neill, S. Steenken and D. Schulte-Frohlinde, J. Phys. Chem., 1975, 79, 2773-2779.

11 C. C. de Araujo, K. D. Kreuer, M. Schuster, G. Portale, H. Mendil-Jakani, G. Gebelb and J. Maiera, Phys. Chem. Chem. Phys., 2009, 11, 3305-3312.

12 G. V. Buxton, C. L. Greenstock, W. P. Helman and A. B. Ross, J. Phys. Chem. Ref. Data, 1988, 17, 513-886.

13 R. H. Schuler, L. K. Patterson and E. Janata, J. Phys. Chem., 1980, 84, 2088-2089.

14 R. H. Schuler, A. L. Hartzell and B. Behar, J. Phys. Chem., 1981, 85, 192-199.

15 G. Wenz, C. Strassnig, C. Thiele, A. Engelke, B. Morgenstern and K. Hegetschweiler, Chemistry, 2008, 14, 7202-7211.

16 E. C. Anderson, R. J. Biediger, J. Chen, B. Dupre, P. Lory, R. V. Market, K. A. Monk, M. M. Savage, R. Tennyson and B. M. Young, US201029753, 2010, p. A1.

17 T. Nauser, G. Casi, W. H. Koppenol and C. Schoneich, J. Phys. Chem. B, 2008, 112, 15034-15044.

18 T. Nauser, PhD Thesis, 1996, DOI: 10.3929/ethz-a001591471.

19 B. S. Wolfenden and R. L. Willson, J. Chem. Soc., Perkin Trans. II, 1982, 805-812.

20 S. L. Scott, W. J. Chen, A. Bakac and J. H. Espenson, J. Phys. Chem., 1993, 97, 6710-6714.

21 I. R. Ilyasov, V. L. Beloborodov and I. A. Selivanova, Chem. Pap., 2018, 72, 1917-1925.

22 L. Ashton, G. V. Buxton and C. R. Stuart, J. Chem. Soc., Faraday Trans., 1995, 91, 1631-1633.

23 J. Zu, R. Liu, Y. Wie, P. Wang, H. Fu, F. Tang and L. He, Res. Chem. Intermed., 2016, 42, 2883-2898. 
24 A. H. Kunz, J. Am. Chem. Soc., 1931, 53, 98-102.

25 X.-M. Pan, M. N. Schuchmann and C. von Sonntag, J. Chem. Soc., Perkin Trans. 2, 1993, 289-297.

26 F. Minisci, T. Caronna, M. Cecere, R. Galli and V. Malatesta, Tetrahedron Lett., 1968, 5609-5612.

27 G. V. Buxton, J. R. Langan and J. R. L. Smith, J. Phys. Chem., 1986, 90, 6309-6313.

28 K.-M. Lee, M. S. Kim and C. Lee, Sustainable Environ. Res., 2016, 26, 177-183.
29 T. M. Nolte, T. Nauser and L. Gubler, Phys. Chem. Chem. Phys., 2020, 22, 4516-4525.

30 T. Nauser, G. Casi, W. H. Koppenol and C. Schöneich, J. Phys. Chem. B, 2008, 112(47), 15034-15044.

31 P. Wardman, J. Phys. Chem. Ref. Data, 1989, 18 1637-1755.

32 R. G. Amballa, C. S. Veeravalli, R. K. Ganta, R. B. Korupolu and A. Nowduri, Zeitschrift für Physikalische Chemie, 2018, 232, 223-244. 